NASA/TM-1999-209379

IECEC 99-01-2678

\title{
Refractive Secondary Concentrators for Solar Thermal Applications
}

Wayne A. Wong

Glenn Research Center, Cleveland, Ohio

Robert P. Macosko

Analex Corporation, Brook Park, Ohio 
Since its founding, NASA has been dedicated to the advancement of aeronautics and space science. The NASA Scientific and Technical Information (STI) Program Office plays a key part in helping NASA maintain this important role.

The NASA STI Program Office is operated by Langley Research Center, the Lead Center for NASA's scientific and technical information. The NASA STI Program Office provides access to the NASA STI Database, the largest collection of aeronautical and space science STI in the world. The Program Office is also NASA's institutional mechanism for disseminating the results of its research and development activities. These results are published by NASA in the NASA STI Report Series, which includes the following report types:

- TECHNICAL PUBLICATION. Reports of completed research or a major significant phase of research that present the results of NASA programs and include extensive data or theoretical analysis. Includes compilations of significant scientific and technical data and information deemed to be of continuing reference value. NASA's counterpart of peerreviewed formal professional papers but has less stringent limitations on manuscript length and extent of graphic presentations.

- TECHNICAL MEMORANDUM. Scientific and technical findings that are preliminary or of specialized interest, e.g., quick release reports, working papers, and bibliographies that contain minimal annotation. Does not contain extensive analysis.

- CONTRACTOR REPORT. Scientific and technical findings by NASA-sponsored contractors and grantees.
- CONFERENCE PUBLICATION. Collected papers from scientific and technical conferences, symposia, seminars, or other meetings sponsored or cosponsored by NASA.

- SPECIAL PUBLICATION. Scientific, technical, or historical information from NASA programs, projects, and missions, often concerned with subjects having substantial public interest.

- TECHNICAL TRANSLATION. Englishlanguage translations of foreign scientific and technical material pertinent to NASA's mission.

Specialized services that complement the STI Program Office's diverse offerings include creating custom thesauri, building customized data bases, organizing and publishing research results ... even providing videos.

For more information about the NASA STI Program Office, see the following:

- Access the NASA STI Program Home Page at http://www.sti.nasa.gov

- E-mail your question via the Internet to help@sti.nasa.gov

- Fax your question to the NASA Access Help Desk at (301) 621-0134

- Telephone the NASA Access Help Desk at (301) 621-0390

- Write to:

NASA Access Help Desk

NASA Center for AeroSpace Information 7121 Standard Drive

Hanover, MD 21076 
NASA/TM-1999-209379

IECEC 99-01-2678

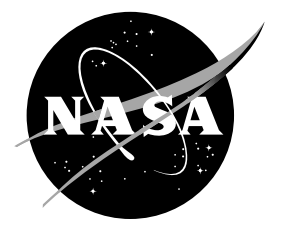

\section{Refractive Secondary Concentrators for Solar Thermal Applications}

Wayne A. Wong

Glenn Research Center, Cleveland, Ohio

Robert P. Macosko

Analex Corporation, Brook Park, Ohio

Prepared for the

34th Intersociety Energy Conversion Engineering Conference sponsored by the Society of Automotive Engineers

Vancouver, British Columbia, Canada, August 1-5, 1999

National Aeronautics and

Space Administration

Glenn Research Center 


\section{Acknowledgments}

The authors wish to acknowledge the technical contributions of Don Buchele, Charlie Castle, Steve Geng, Eric Golliher, Nate Jacobson, Don Jaworske, Carol Tolbert and Dongming Zhu for their invaluable support in the development of the refractive secondary concentrator technology. The authors are also grateful to Richard Shaltens and Leslie Curtis for their programmatic support to the development effort.

Available from

NASA Center for Aerospace Information 7121 Standard Drive

Hanover, MD 21076

Price Code: A03
National Technical Information Service 5285 Port Royal Road Springfield, VA 22100 Price Code: A03 


\title{
Refractive Secondary Concentrators for Solar Thermal Applications
}

\author{
Wayne A. Wong \\ National Aeronautics and Space Administration \\ Glenn Research Center \\ Cleveland, Ohio \\ Robert P. Macosko \\ Analex Corporation \\ Brook Park, Ohio
}

\begin{abstract}
The NASA Glenn Research Center is developing technologies that utilize solar energy for various space applications including electrical power conversion, thermal propulsion, and furnaces. Common to all of these applications is the need for highly efficient, solar concentration systems. An effort is underway to develop the innovative single crystal refractive secondary concentrator, which uses refraction and total internal reflection to efficiently concentrate and direct solar energy. The refractive secondary offers very high throughput efficiencies (> 90\%), and when used in combination with advanced primary concentrators, enables very high concentration ratios $(10,000$ to 1$)$ and very high temperatures (> $2000 \mathrm{~K})$.
\end{abstract}

Presented is an overview of the refractive secondary concentrator development effort at the NASA Glenn Research Center, including optical design and analysis techniques, thermal modeling capabilities, crystal materials characterization testing, optical coatings evaluation, and component testing. Also presented is a discussion of potential future activity and technical issues yet to be resolved. Much of the work performed to date has been in support of the NASA Marshall Space Flight Center's Solar Thermal Propulsion Program. The many benefits of a refractive secondary concentrator that enable efficient, high temperature thermal propulsion system designs, apply equally well to other solar applications including furnaces and power generation systems such as solar dynamics (i.e. Brayton, Stirling), concentrated thermal photovoltaics, and thermionics.

\section{INTRODUCTION}

Space solar applications have been identified that will require efficient, light weight energy delivery systems that can enable the high temperatures required by these systems. Proposed power and propulsion systems have temperature requirements in excess of $2000 \mathrm{~K}$, driving the concentration ratio requirement of the energy delivery system to as high as 10,000:1 and also requiring very precise pointing and control systems.
Light weight, thin film, deployable primary concentrators have been proposed for these systems. No primary concentrator technology is capable of achieving the system requirements alone, thus necessitating the addition of a secondary concentrator to the energy delivery system.

The innovative high efficiency refractive secondary concentrator, figure 1, offers significant advantages over all other types of secondaries and is an enabling technology for ultra high temperature thermal applications ( 2000 K or higher). The refractive secondary offers the highest throughput efficiency, provides for flux tailoring, requires no active cooling, relaxes the pointing and tracking requirements of the primary concentrator, and enables very high system concentration ratios.

The development of the refractive secondary concentrator at the NASA Glenn Research Center (GRC) was initiated in support of the NASA MSFC's Shooting Star solar thermal propulsion flight Experiment (SSE). Figure 2 is a conceptual layout of the refractive secondary concentrator integrated with the SSE engine. Cancellation of the SSE due to funding constraints has resulted in a reduced refractive secondary development

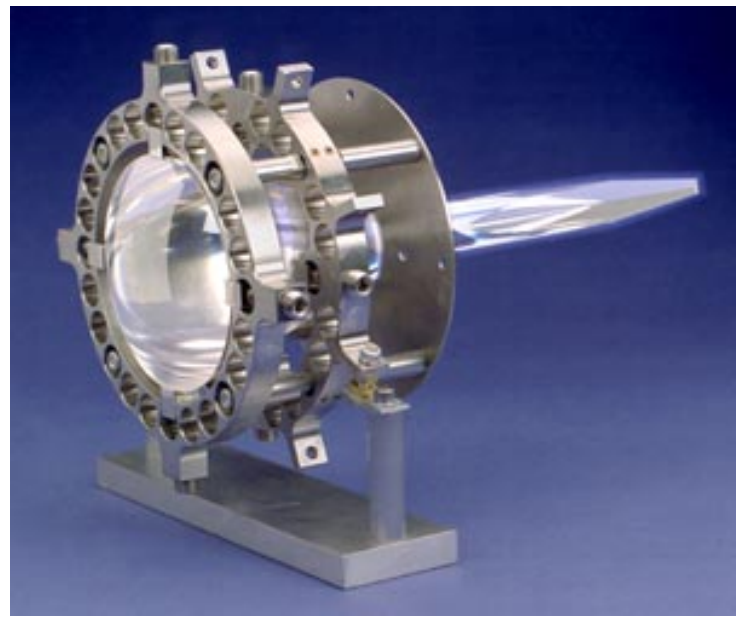

Figure 1 - Prototype refractive secondary concentrator 
effort. Although the refractive secondary concentrator development to date has been for application in thermal propulsion systems, its many advantages apply equally well to other solar applications such as power generation and solar furnaces.

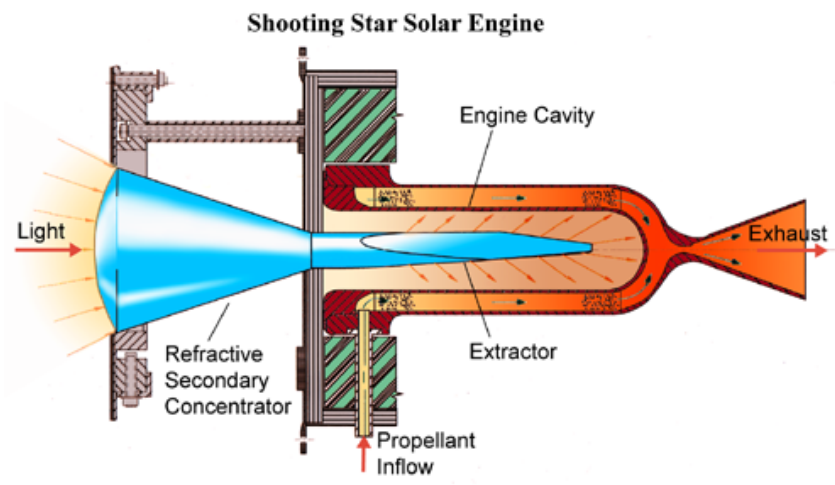

Figure 2 - Refractive secondary integrated with the Shooting Star solar thermal propulsion engine

\section{DESCRIPTION OF REFRACTIVE SECONDARY CONCENTRATORS}

The innovative refractive secondary concentrator, made of solid single crystal material, uses refraction and total internal reflection to focus and direct the solar flux. Integral to the design of the refractive secondary is the flux extractor, which allows the efficient extraction and tailored distribution of the concentrated solar energy. Figure 3 illustrates graphically, via ray tracing, the transmission of solar energy through the refractive secondary to its point of use, in this case the SSE engine cavity.

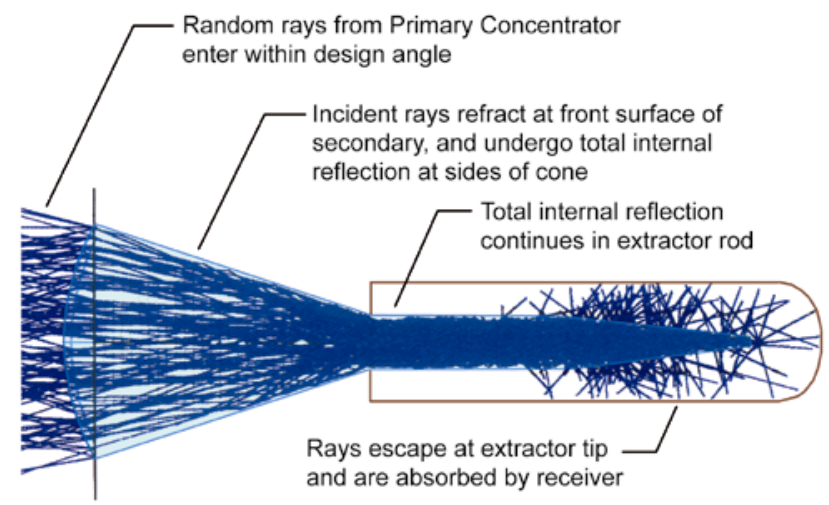

Figure 3 - Refractive secondary concentrates solar energy via refraction and total internal reflection

The refractive secondary has numerous design advantages over the conventional reflective secondary concentrator, typically envisioned as a hollow cone with a reflective internal surface. Figure 4 illustrates the significant advantages of the refractive secondary concentrator compared to the reflective secondary concentrator that make it attractive to a broad variety of solar applications. The benefits of the refractive secondary are:
- Higher Throughput Efficiency

- Higher Concentration Ratio

- Tailored Energy Distribution

- Requires no active cooling

- Improved Performance using Optical Coatings

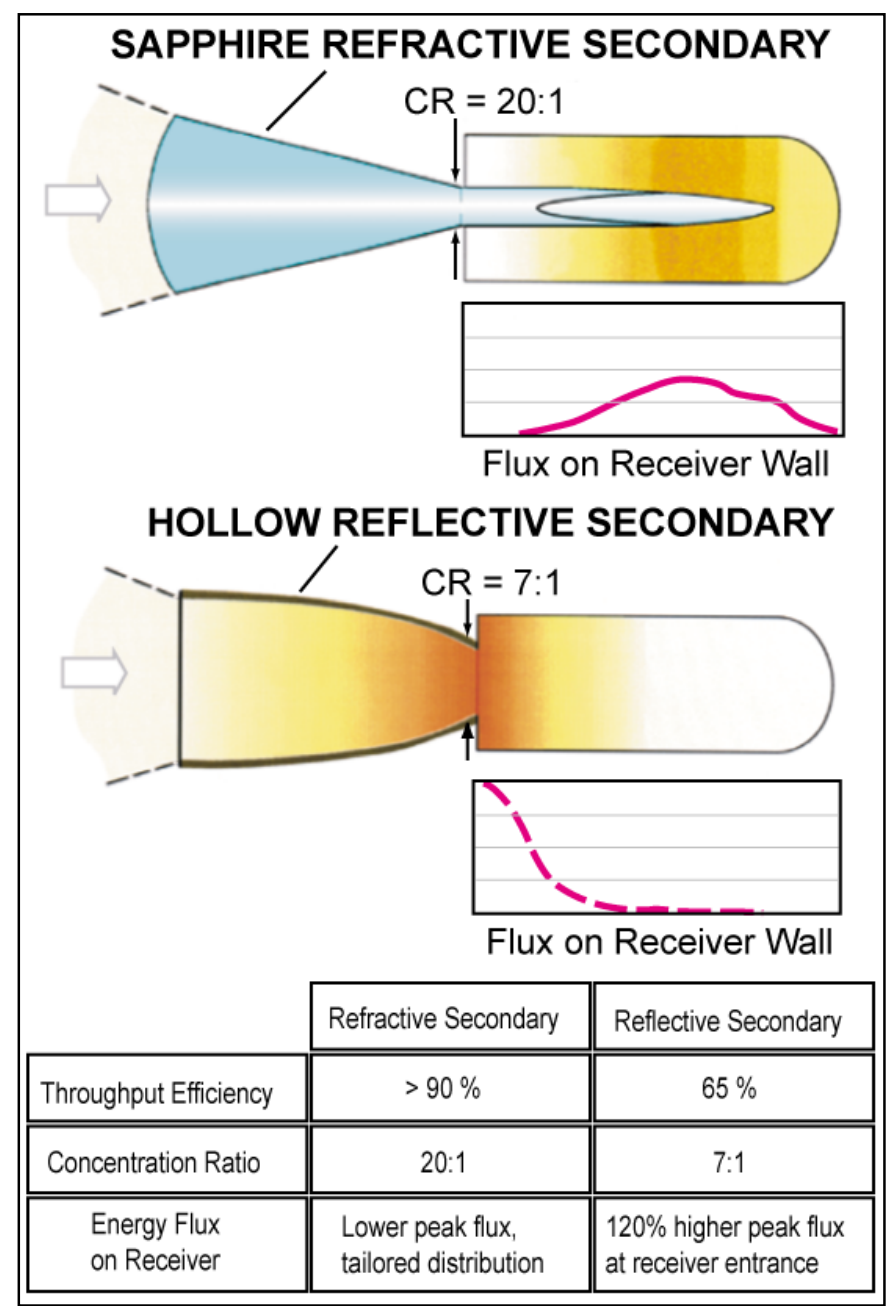

Figure 4 - Refractive secondary has many benefits compared to the conventional reflective secondary

\section{HIGHER THROUGHPUT EFFICIENCY}

Solar energy entering the secondary is refocused by refraction and total internal reflection both of which are essentially loss-less mechanisms. The only throughput losses associated with the refractive secondary are due to reflection at the inlet surface (which can be minimized with coatings), absorption in the crystal (which for candidate materials like sapphire is very low), and back reflection within the crystal (which is minimized through design). The throughput efficiency of the refractive secondary has been estimated to be in excess of $90 \%$ for the designs and materials under consideration. In comparison, the reflective secondary efficiency is reduced due to energy absorption at the reflective surface which is as high as 35\% depending on the reflective coating used and the operating temperature. 


\section{HIGH CONCENTRATION RATIO}

The refractive secondary produces concentration ratios many times larger than an equivalent reflective secondary for the same inlet condition. A typical design using sapphire for the refractive secondary has a concentration ratio of 20:1 compared with 7:1 for a reflective secondary. Therefore the refractive secondary can lessen the concentration ratio and/or pointing accuracy requirement of the primary concentrator or allow higher operating temperatures.

\section{TAILORED ENERGY DISTRIBUTION}

The flux extractor, a faceted extended tip, is an essential part of the refractive secondary design. It is needed to efficiently pass the concentrated solar energy into the receiver cavity and allows for flux tailoring via the adjustment of the facet geometry. Unlike the reflective secondary, which directs most of the energy at the front of the receiver cavity, the refractive secondary and extractor can be designed to allow more uniform energy distribution further into the cavity. The flux extractor serves as a light pipe to efficiently deliver the energy to the point of extraction. Variations of extractor designs are envisioned for eliminating hot spots, customized for each application (i.e. solar dynamic conversion heat receiver, thermal photovoltaic array (TPV), thermionic diodes, thermal propulsion, furnaces, etc.)

\section{REQUIRES NO ACTIVE COOLING}

A refractive secondary does not require active cooling because little incident energy is absorbed, and misalignment can be tolerated with minimal impact on performance. In comparison, reflective secondaries are limited in application due to the reduction in reflectivity of the surface material at temperatures above $1500 \mathrm{~K}$ and their need for active cooling in high temperature applications. In addition, high power applications may introduce troublesome thermal management issues for reflective secondaries, especially if off-pointing or misalignment occurs which can cause uneven heating and distortion of the reflective secondary surface.

\section{IMPROVED PERFORMANCE USING OPTICAL COATINGS}

An anti-reflective coating on the refractive secondary inlet surface minimizes incident reflection losses. Of even greater significance for high temperature applications is the use of the refractive secondary with an infrared (IR) retainment element at the inlet of the secondary. At temperatures in excess of $1000 \mathrm{~K}$, typical of many solar thermal applications, the IR radiation loss out of the open aperture of the heat receiver becomes substantial. In order to reduce the radiation loss, and thereby improve the overall system efficiency, a coated element, reflective in the IR spectrum, can reflect back the infrared radiation leaving the cavity, reducing the net radiation loss. Analysis has shown that this coated element can potentially reflect as much as $80 \%$ of the radiant energy that would have otherwise been lost through the receiver aperture while only blocking a small portion of the incident solar energy.

\section{ACCOMPLISHMENTS}

The refractive secondary concentrator for high temperature applications is in the early stages of development. Accomplishments to date include:

\section{DEVELOPMENT OF OPTICAL DESIGN AND MODELING TECHNIQUES}

The design methodology of the refractive secondary front end, or "cone," has been covered by Soules, et al (ref. 1). Once the geometry of the cone has been determined, a ray trace modeling technique is used to assess the performance of the entire refractive secondary concentrator and to determine an optimum geometry for the extractor. It is important to point out that the performance of the refractive secondary is dependent on the flux profile from the primary concentrator, and that ideally, the primary and secondary concentrators should be designed together as an optical system.

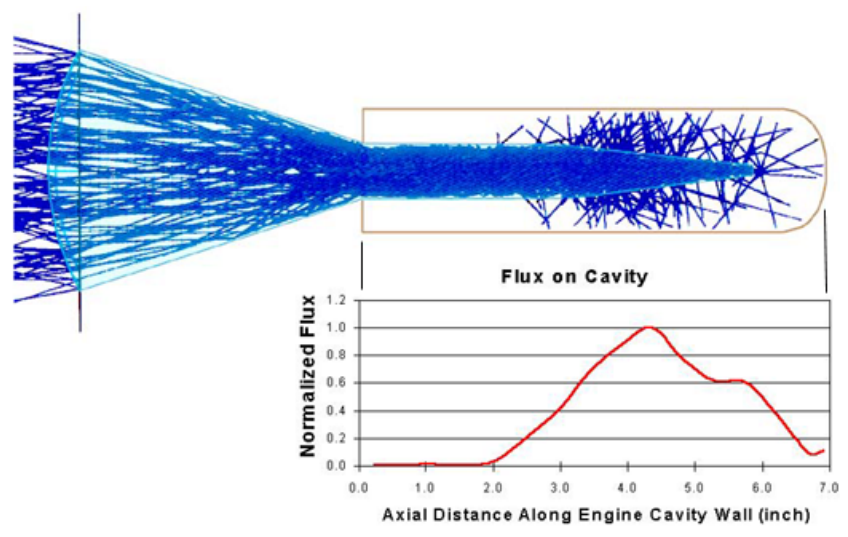

Figure 5 - Ray trace model predicts flux distribution inside engine receiver

Figures 5 and 6 are representative of results obtained from the ray trace model. Figure 5 illustrates a ray trace using a bundle of converging random rays within a prescribed design half angle of 22 degrees as the source, showing the rays as they travel through the refractive secondary body and extractor before escaping via the extractor facets. Below the ray trace illustration is a data plot of the normalized flux along the engine receiver wall. By design, no energy escapes in the straight front section of the extractor; rather, it escapes at the facets and impinges on the cavity wall deeper in the receiver avoiding a flux peak at the entrance of the cavity.

Figure 6(a) is a wire frame of the ray trace model including a plane perpendicular to the axis of the secondary. Figure $6(\mathrm{~b})$ is an intensity map of the flux on the plane and figure 6 (c) is a plot of the flux as a function of radius from the center of the plane. The model reveals that, as seen in figures $6(\mathrm{~b})$ and $6(\mathrm{c})$, the flux exiting the refractive secondary creates a cone of dispersion that impinges on the plane forming a distinct area of illumination that has higher intensity near the center and tapers off at the edges. The flux distributions shown in figure 5 and figure 6(c) are 


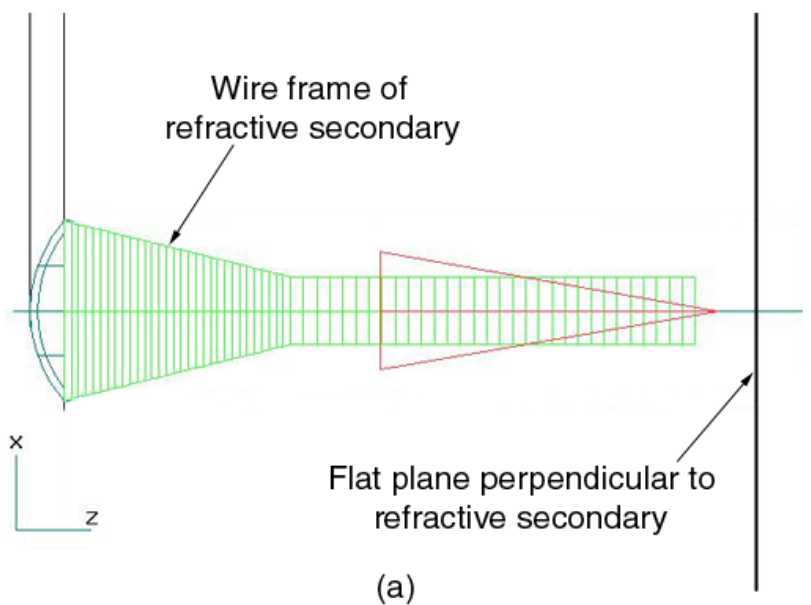

(a)

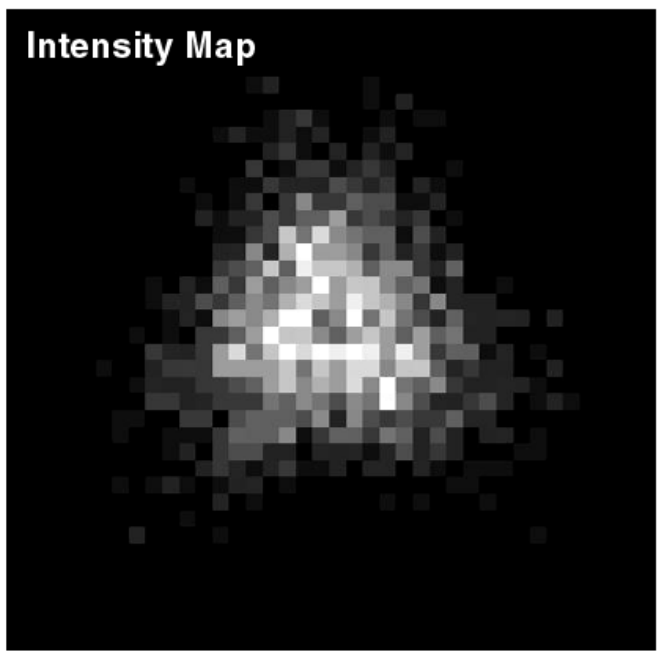

(b)

$F$ lu $x$ Projected on to $P$ erpendicular $P$ la ne

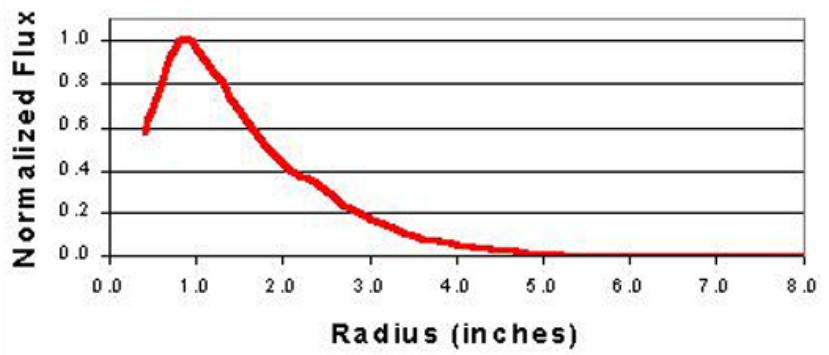

(c)

Figures 6(a) - Ray trace model of refractive secondary shown with a plane perpendicular to secondary, $6(\mathrm{~b})$ Intensity map indicating the flux distribution on the plane, and 6(c) Normalized flux as a function of radius from the center of the plane

dependent on the extractor design which can be customized in order to optimize system performance.

\section{DEVELOPMENT OF TRANSIENT THERMAL MODEL}

The transient 3-D thermal analysis used to model the refractive secondary concentrator and receiver is described in detail by Geng, et al (Ref. 2). In summary, the thermal analysis compares the thermal response of a refractive secondary made of sapphire with that made of zirconia over multiple sun/shade orbits. A representative thermal profile of a zirconia refractive secondary in the SSE engine at temperature is shown in figure 7. Results indicate that a significant thermal gradient develops at the transition between the refractive secondary cone and the extractor once the cavity achieves high temper-atures, and that the gradient is less severe in the case of sapphire.

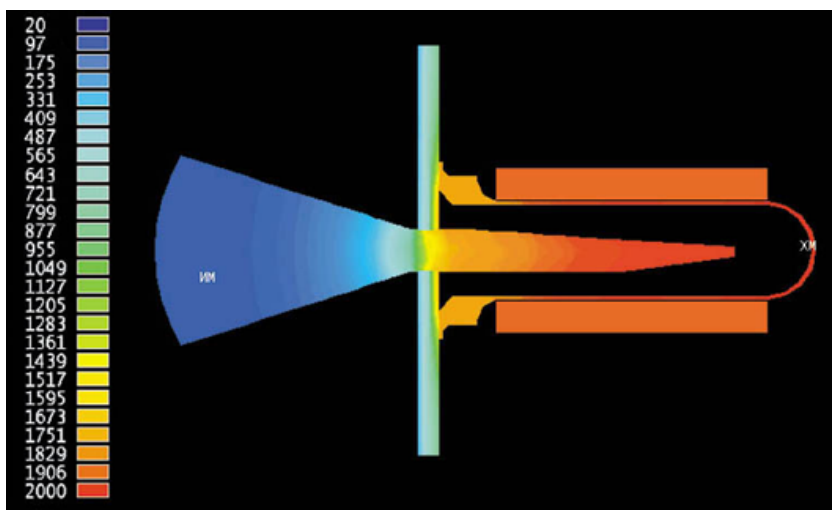

Figure 7 -Transient thermal model of the refractive secondary mated with the Shooting Star engine

\section{MATERIALS CHARACTERIZATION}

Critical to the success of the refractive secondary concentrator in high power solar applications, is the selection of material from which to fabricate the secondary. The requirements of the refractive secondary are many, including high temperature, large thermal gradients, thermal shock when the sun is engaged, thermal cycling during sun/shade orbits, launch survivability, and material chemical compatibility. Much work has been performed to address some of these issues, particularly thermal shock, in order to guide the material selection process as described by Zhu, et al (ref. 3). Figure 8 shows photographs of crystal samples that have undergone destructive thermal shock testing.

Figure 9 plots the results of thermal shock tests on samples of three candidate crystal materials, zirconia, YAG, and sapphire, indicating for each sample, the critical power density, the surface temperatures, and the temperature difference across the sample, when fracture occurred. The evaluation results for sapphire are very encouraging indicating that, in comparison to other materials under consideration, it is the most rugged with regard to tolerance of thermal shock. Notice that sapphire $\left(\mathrm{Al}_{2} \mathrm{O}_{3}\right)$ has a consistently higher critical power density and larger temperature difference across the sample. 


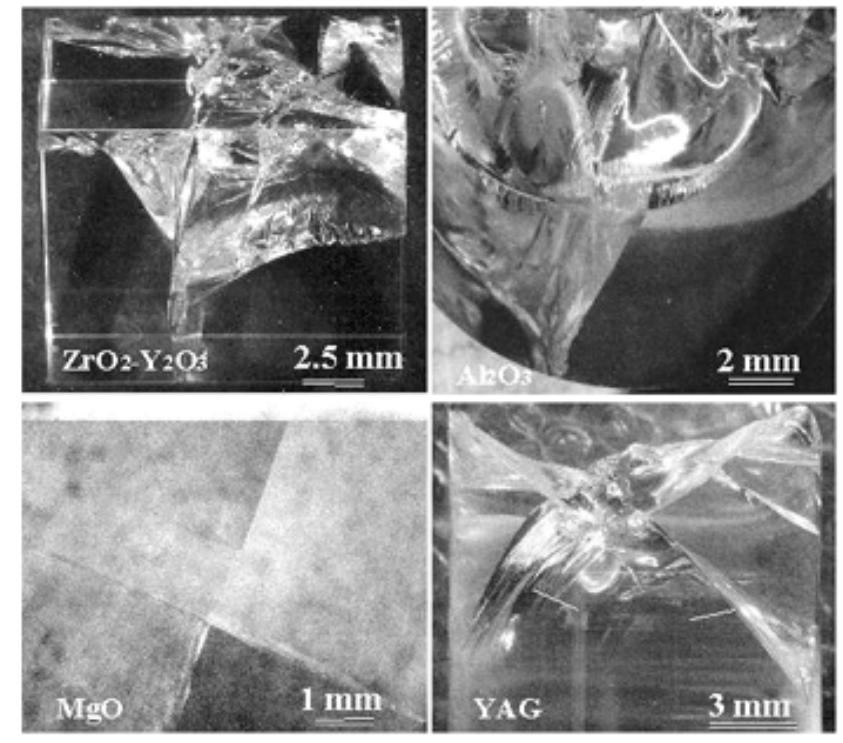

Figure 8 - Samples of candidate materials characterized during destructive thermal shock testing

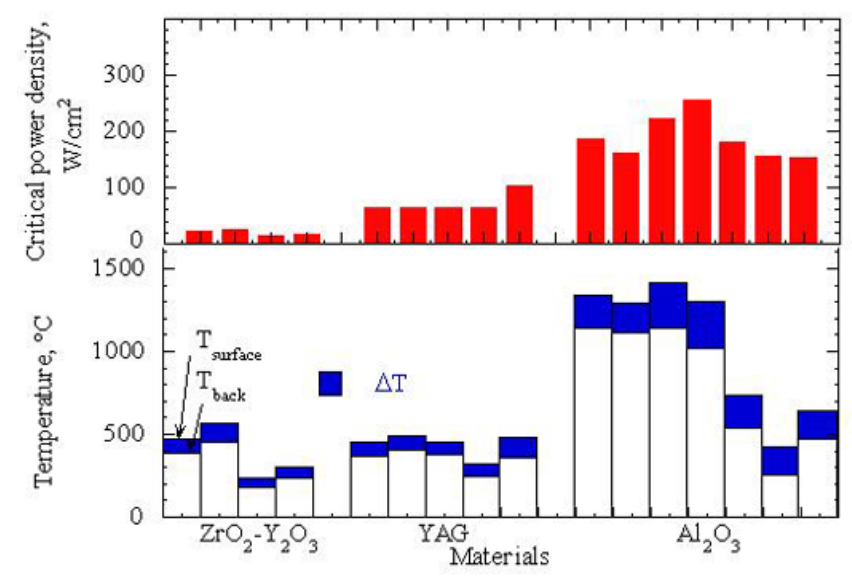

Figure 9 - Thermal shock tests indicate sapphire $\left(\mathrm{Al}_{2} \mathrm{O}_{3}\right)$ has significantly better thermal stress resistance than other candidate materials

\section{PROTOTYPE FABRICATION}

The feasibility of fabricating the refractive secondary cone and extractor geometries has been verified. Refractive secondary prototypes have been fabricated of both acrylic and zirconia. The zirconia prototype, housed within its support structure, is shown in figure 1. The acrylic demonstrator is shown in figure 10 transmitting a laser beam.

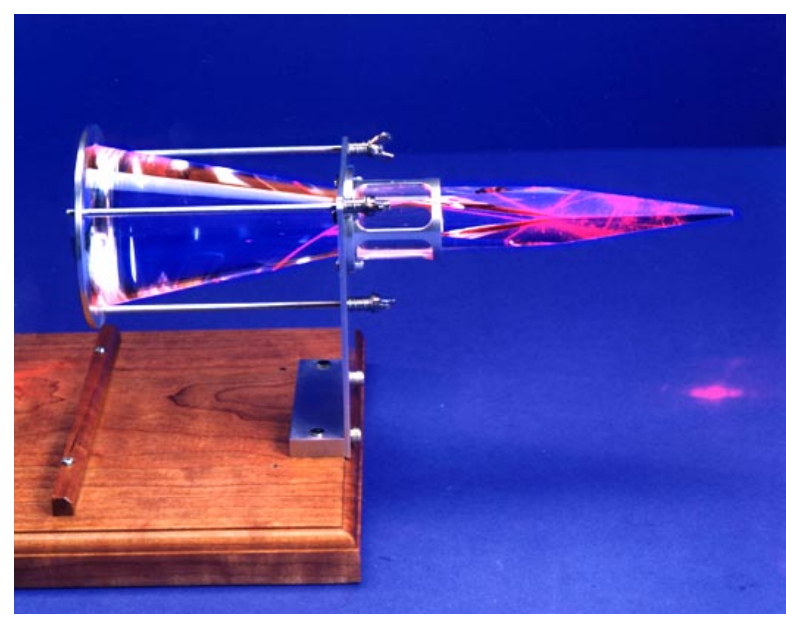

Figure 10 - A laser beam travels through the acrylic demonstrator

\section{COMPONENT TESTING}

To substantiate the optical design and modeling techniques, the acrylic prototype has undergone evaluation on an optics bench as described by Jaworske, et al (Ref. 4). In summary, a laser was used to evaluate, for a given laser input condition, the resulting energy output from the refractive secondary. Results from the evaluation were compared to results from the ray trace model, showing very good correlation between the two.

In addition, the zirconia prototype was used in a preliminary on-sun test in the Solar Facility at the University of Alabama in Huntsville. Figure 11 is a photograph of the set up during testing. Due to instrumentation issues, this preliminary test was not conclusive.

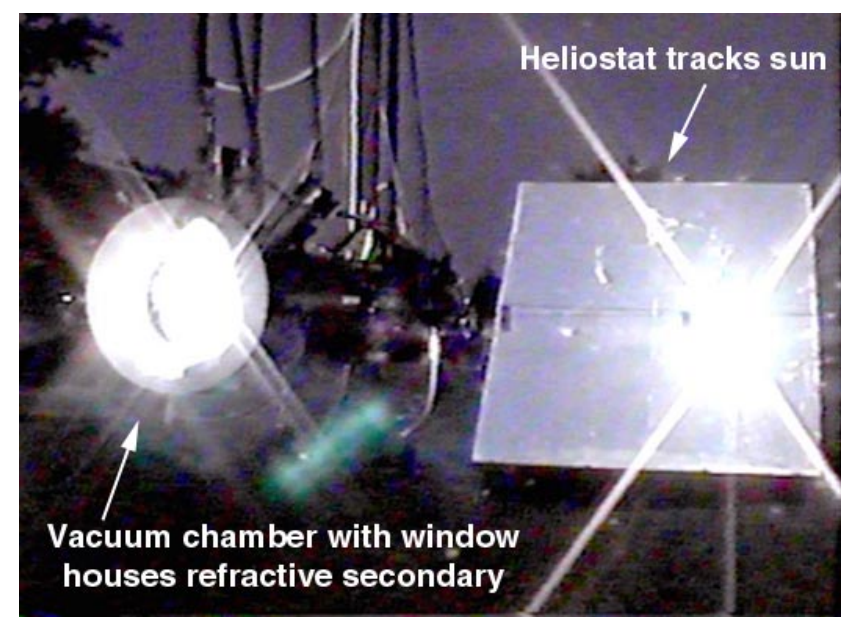

Figure 11 - Prototype refractive secondary under test at the University of Alabama in Huntsville 


\section{POTENTIAL FUTURE ACTIVITY}

The technology progression requires on-sun proof of concept tests for the refractive secondary in a relevant environment to evaluate efficiency and demonstrate high temperature, high power performance. Additional tests of the refractive secondary integrated with advanced light weight concentrators would establish the technologies on a system level. A thermal vacuum facility equipped with a solar simulator at NASA GRC is ideally suited for these tests.

In addition, as previously discussed, material characterization is of utmost importance. Material properties, limitations, stability, and chemical compatibility has to be further analyzed and evaluated. There is little to no data base on the properties of the candidate materials at the very high operating temperatures required by some applications. In addition, while evaluation results for sapphire to date are encouraging, sapphire is not suitable for some of the high temperature applications that have been envisioned (> $2300 \mathrm{~K}$, sapphire's melt point). Thus other materials have to be sought, or developed, for these applications.

Preliminary analysis at GRC has indicated that an IR blocker (reflective element), used in conjunction with a refractive secondary concentrator will result in substantial improvements in performance of systems that operate at high temperature. IR losses through the aperture become dominant in systems that operate at temperatures higher than $1000 \mathrm{~K}$. The use of an IR blocker can retain as much as $80 \%$ of the energy that would have otherwise been lost. The IR blocker needs to be developed beyond this preliminary analysis.

\section{SUMMARY AND CONCLUDING REMARKS}

The innovative refractive secondary concentrator is an enabling technology for solar applications that require high efficiency, high temperature, and high concentration ratio. The refractive secondary is particularly attractive when used in combination with thin film, deployable primary concentrators to form a light weight, efficient solar energy delivery system.

Optical analysis and thermal modeling has shown that a refractive secondary concentrator, designed specifically for the SSE, made of single crystal sapphire has the potential of greater than $90 \%$ throughput efficiency. The concentrator can provide tailored flux distribution into a heat receiver cavity, at cavity wall operating temperatures exceeding $2000 \mathrm{~K}$. The device does not require active cooling and when coupled with an infrared reflector element can save as much as $80 \%$ of the infrared energy normally lost through the cavity aperture. Thermal shock testing at the GRC has demonstrated the excellent performance of sapphire for this application.

Efforts to develop the refractive secondary concentrator to date have been very encouraging, however there is much that needs to be done in order to bring the technology to a level so that it can be used in actual application.

\section{REFERENCES}

1. J.A. Soules, D.R. Buchele, C.H. Castle, and R.P. Macosko, "Design and Fabrication of a Dielectric Total Internal Reflecting Solar Concentrator and Associated Flux Extractor for Extreme High Temperature (2500 K) Applications," NASA Lewis Research Center, Cleveland, Ohio, NASA CR204145, November 1997.

2. S.M. Geng, and R.P. Macosko, "Transient Thermal Analysis of a Refractive Secondary Solar Concentrator," NASA Glenn Research Center, Cleveland, Ohio, IECEC 1999-01-2680, August 1999.

3. D. Zhu, N.S. Jacobson and R.A. Miller, "ThermalMechanical Stability of Single Crystal Oxide Refractive Concentrators for High-Temperature Solar Thermal Propulsion," NASA Lewis Research Center, Cleveland, Ohio, NASA TM 1999-208899, February 1999.

4. D.A. Jaworske, W.A. Wong and T.J. Skowronski, "Optical Evaluation of a Refractive Secondary Concentrator," NASA Glenn Research Center, Cleveland, Ohio, IECEC 1999-01-2679, August 1999. 
Public reporting burden for this collection of information is estimated to average 1 hour per response, including the time for reviewing instructions, searching existing data sources, gathering and maintaining the data needed, and completing and reviewing the collection of information. Send comments regarding this burden estimate or any other aspect of this collection of information, including suggestions for reducing this burden, to Washington Headquarters Services, Directorate for Information Operations and Reports, 1215 Jefferson Davis Highway, Suite 1204, Arlington, VA 22202-4302, and to the Office of Management and Budget, Paperwork Reduction Project (0704-0188), Washington, DC 20503.

\begin{tabular}{|l|l|l}
\hline 1. AGENCY USE ONLY (Leave blank) & $\begin{array}{c}\text { 2. REPORT DATE } \\
\text { July } 1999\end{array}$ & $\begin{array}{r}\text { 3. REPORT TYPE AND DATES COVERED } \\
\text { Technical Memorandum }\end{array}$ \\
\hline
\end{tabular}

\section{TITLE AND SUBTITLE}

Refractive Secondary Concentrators for Solar Thermal Applications

\section{6. $\operatorname{AUTHOR(S)}$}

Wayne A. Wong and Robert P. Macosko

\section{PERFORMING ORGANIZATION NAME(S) AND ADDRESS(ES)}

National Aeronautics and Space Administration

John H. Glenn Research Center at Lewis Field

Cleveland, Ohio 44135-3191

\section{SPONSORING/MONITORING AGENCY NAME(S) AND ADDRESS(ES)}

National Aeronautics and Space Administration

Washington, DC 20546-0001

\section{FUNDING NUMBERS}

WU-632-81-0A-00
8. PERFORMING ORGANIZATION REPORT NUMBER

E-11793

\section{SUPPLEMENTARY NOTES}

Prepared for the 34th Intersociety Energy Conversion Engineering Conference sponsored by the Society of Automotive Engineers, Vancouver, British Columbia, Canada, August 1-5, 1999. Wayne A. Wong, NASA Glenn Research Center, and Robert P. Macosko, Analex Corporation, Brook Park, Ohio 44142. Responsible person, Wayne A. Wong, organization code 5490, (216) 433-6318.

Unclassified - Unlimited

Subject Categories: 20 and 44

Distribution: Nonstandard

This publication is available from the NASA Center for AeroSpace Information, (301) 621-0390.

\section{ABSTRACT (Maximum 200 words)}

The NASA Glenn Research Center is developing technologies that utilize solar energy for various space applications including electrical power conversion, thermal propulsion, and furnaces. Common to all of these applications is the need for highly efficient, solar concentration systems. An effort is underway to develop the innovative single crystal refractive secondary concentrator, which uses refraction and total internal reflection to efficiently concentrate and direct solar energy. The refractive secondary offers very high throughput efficiencies (>90\%), and when used in combination with advanced primary concentrators, enables very high concentration ratios $(10,000$ to 1$)$ and very high temperatures $(>2000 \mathrm{~K})$. Presented is an overview of the refractive secondary concentrator development effort at the NASA Glenn Research Center, including optical design and analysis techniques, thermal modeling capabilities, crystal materials characterization testing, optical coatings evaluation, and component testing. Also presented is a discussion of potential future activity and technical issues yet to be resolved. Much of the work performed to date has been in support of the NASA Marshall Space Flight Center's Solar Thermal Propulsion Program. The many benefits of a refractive secondary concentrator that enable efficient, high temperature thermal propulsion system designs, apply equally well to other solar applications including furnaces and power generation systems such as solar dynamics (i.e. Brayton, Stirling), concentrated thermal photovoltaics, and thermionics.

\section{SUBJECT TERMS}

Solar collectors; Secondary concentrators; Solar energy; Solar power generation; Solar propulsion; Solar furnaces

\begin{tabular}{|c|c|}
\hline $\begin{array}{c}\text { 17. SECURITY CLASSIFICATION } \\
\text { OF REPORT } \\
\text { Unclassified }\end{array}$ & $\begin{array}{c}\text { 18. SECURITY CLASSIFICATION } \\
\text { OF THIS PAGE } \\
\text { Unclassified }\end{array}$ \\
\hline
\end{tabular}

19. SECURITY CLASSIFICATION
OF ABSTRACT
Unclassified

Standard Form 298 (Rev. 2-89)

Prescribed by ANSI Std. Z39-18 298-102 